\title{
THE IMPACT OF HUMAN RESOURCE MANAGEMENT ON TECHNOLOGICAL INNOVATION IN JUBAIL PRIMARY INDUSTRIAL SECTOR, KINGDOM OF SAUDI ARABIA
}

\author{
MANAL AL-GHAMDI, REFAAT ABDEL-RAZEK
}

\begin{abstract}
:
People are important in enhancing industrial firms' performance and in creating competitive advantage. High quality human resources management enable firms to compete upon the quality of product and services, differentiated products and technological innovation. The importance of effective people management to successful technological innovation capability has been recognized for some time, yet little comparative data is available to explain the complex relationship between human resources management and the technological innovation performance in Saudi Arabia. The objective of this study is to examine the relationship between human resources management (HRM) and organizations' technological innovation in a large industrial sector in Saudi Arabia. This study was applied on the primary industrial companies in Jubail industrial city. Two surveys were administered to the Jubail primary industrial companies; the first survey used the Organization for Economic Co-operation and Development (OECD) questionnaire to measure the companies' technological innovation, the second survey was designed by the researcher to measure the implementation of HRM system in the same companies. Correlation between HRM and organizations' technological innovation was measured. Statistical analysis was used to analyze the obtained data. The results showed that the HRM can influence the technological innovation in Jubail primary industrial organizations. It also showed that enhancing technological innovation in industrial organizations is possible through integrating HRM practices, developing HR activities and emphasizing on HR role in the industrial organizations' strategic planning. The results also revealed that the development of technological abilities of human resources in Jubail primary industrial organizations can positively affect product innovation and reduce the effects of cost and knowledge factors hampering technological innovation in Jubail primary industrial companies. Recognition and reward system also has a positive effect on improving innovation. The methodology used to evaluate the relationship between HRM and technological innovation is suitable and could be used to enhance technological innovation in industrial organizations. This study recommends that HRM should be considered as an enhancement to the technological innovation in the industrial sector. However, HR indicators must be evaluated as a whole module of practices instead of concentrating on each indicator individually.
\end{abstract}

\section{Keywords:}

Competitive Advantage, HR Technology, Human Resources Management, Industrial Organizations, Saudi Arabia, Technological Innovation.

JEL Classification: 032

\section{Authors:}


MANAL AL-GHAMDI, Arab Open Unversity, Saudi Arabia, Email: mghamdi@arabou.edu.sa

REFAAT ABDEL-RAZEK, Arabian Gulf University, Bahrain, Email: refaathar@agu.edu.bh

\section{Citation:}

MANAL AL-GHAMDI, REFAAT ABDEL-RAZEK (2015). The Impact of Human Resource Management on Technological Innovation in Jubail Primary Industrial Sector, Kingdom of Saudi Arabia. International Journal of Business and Management, Vol. III(2), pp. 1-17., 10.20472/BM.2015.3.2.001 


\section{Introduction}

In the current competitive globalized marketplace, technological innovation is very critical to the organization success and sustainability. Whereas effective management of an organization's human resources has also become a critical issue for ensuring sustained technological innovation ability. The human recourses management literature emphasizes the importance of people in enhancing industrial firms' performance and creating a competitive advantage. High quality human resources enable organizations to compete on the basis of market responsiveness, quality of product and services, differentiated products, and technological innovation, companies are now trying to add value with their human resources management HRM (Abdullah et al. , 2009). However, a 'bundle' of HR practices need to be combined together to have more influence to an innovative environment (Laursen and Foss, 2003). This study notes the deficit in clear links between human resources management HRM practices and innovation performance and examines the extent to which human recourses management can encourage and sustain organizations' technological innovation in primary industrial companies in Jubail, Saudi Arabia.

\subsection{Research Questions}

HRM systems comprised of specific practices that may influence the technological innovation capacity. This study adapted Jorgensen, Becker \& Mathews (2009) HR practices which are believed to enhance organizations' technological innovation. The following are the research questions to test the HR practices:

1- Does HRM have a direct impact on organizational technological innovation?

2- What valid reliable scale can be used to measure the relationship between the human resources management HRM and organizations' technological innovation?

\subsection{Problem Statement}

Although the importance of effective people management to successful technological innovation capability has been recognized for some time (Hull and Azumi, 1984; Scarbrough 2003), yet Laursen and Foss (2003) argue that from both perspectives, technological innovation management and human resource management, "there is a lack of theoretical and empirical treatment of how new HRM practices affect technological innovation performance".

Moreover, a little comparative data is available to explain the complex relationship between high quality human resources management and the organizational technological innovation performance in the GCC countries (the Arabian Society for Human Resource Management, 2010). In addition, there is no consistent agreement on how to measure effective HRM and clearly classify the exact HRM practices or processes that might be most helpful for building technological innovation capabilities (Jorgensen, Becker \& Matthews 2009).

\subsection{Research Objectives}

The main purpose of this study is to examine the relationship between human resources management and organizations' technological innovation, and the application of the findings on the primary industrial companies in Jubail, Saudi Arabia.

The secondary objective is:

To develop a conceptual model of HR practices that positively affects organization's technological innovation. 


\subsection{Meaning and Definition of Terms:}

\section{Human Resources Management HRM}

Human resources management (HRM) is the management of people in an organization. HRM tools comprise the policies, practices and activities at the disposal of managers to obtain, develop, use, evaluate, maintain and retain the appropriate number, skill mix and motivation of employees to accomplish the organization's objectives (Mathauer and Imhoff, 2006).

\section{Innovation}

The central meaning of innovation thus relates to renewal or improvement, with novelty being a consequence of this improvement. In organizations, innovation is the multi-stage process whereby organizations transform ideas into improved products, service or processes, in order to advance, compete and differentiate themselves successfully in their marketplace ( Baregheh et al. , 2009).

\section{Primary Industries}

An industry involved in the extraction and collection of natural resources. A company in a primary industry can also be involved in turning natural resources into products. (Business Dictionary, 2011).

\section{Literature Review}

\subsection{Types of Innovation}

The Oslo Manual (OECD, 2005) lists four types of innovations: product innovations, process innovations, marketing innovations and organizational innovations:

- A product innovation is the introduction of a good or service that is new or significantly improved with respect to its characteristics or intended uses.

- A process innovation is the implementation of a new or significantly improved production or delivery method.

- A marketing innovation is the implementation of a new marketing method involving significant changes in product design or packaging, product placement, product promotion or pricing.

- An organizational innovation is the implementation of a new organizational method in the firm's business practices, workplace organization or external relations.

\subsection{Domains of Measuring Innovation in Developing Countries}

Oslo Manual 2005 came up with a whole chapter that provides guidelines for measuring innovation and the implementation of innovation surveys in developing countries. Which sees that the innovation measurement in developing countries has to produce results comparable to those obtained in developed countries that use the Oslo Manual in order to enable benchmarking and construct a coherent international system of innovation indicators. At the same time, innovation surveys need to respect and be able to pick up the characteristics of innovation in developing countries such as instability, informality, and weak innovation system. They also need to emphasis on certain aspects of surveys in: Human resources, linkages, information and communication technologies (ICTs), their incorporation and use.

The Oslo Manual (2005), which contains guidelines for collecting and interpreting innovation data have become the reference for various large scale surveys examining the nature and impacts of innovation in the business sector, such as the Community Innovation Survey (CIS). The Oslo 
Manual is a publication of the Organization for Economic Co-Operation and Development OECD and published three times in the years 1992, 1997 and 2005. The CIS4 questionnaire focuses on nine dimensions (1) types of innovation, (2) information on the innovation activities and investments, (3) innovation objectives, (4) sources of information for innovation, (5) innovation collaboration, (6) results of the firm's innovation, (7) factors hampering innovation, (8) profiting from firm's innovation investment, (9) some context information about the firm (Al-Kuaik, 2010).

For innovation indicators to be useful, they must be widely known and accepted as measures of innovation activity (Bloch 2008). Therefore, the CIS4 innovation indicators will be adopted for the use of this study.

\subsection{Human Resource Management HRM}

Many studies identified human resources as a key factor to gaining and sustaining competitive advantage, and have largely overlooked the importance of high quality human resources. High quality human resources enable organizations to compete on the basis of market responsiveness, quality of product and services, differentiated products, and technological innovation (Ulrich 1997).

\subsection{Domains of Measuring HRM}

"Many academicians and professionals do not agree on what to measure as far as effective HRM practices are concerned or how to measure them"( Yoon Cho 2004). The literature reveals a wide range of focal points and presumed central objectives for the various models of HRM (Hester 2005). Redman (2006) suggests that making changes to individual HR practices will have a very limited effect on the organization whereas making changes on a bundle of HR practices together will have a more powerful effect. This leads onto the concept of looking for a 'bundle' of practices which need to be combined together, and the more recent focus on 'bundles' of HRM practices that may prove conducive to an innovative environment (Jorgensen, Becker \& Matthews 2009).

\subsection{Linking HRM and Technological Innovation}

In recent years, the relationship between HRM and innovation has been explored from various angles. Jorgensen et al. (2009) research has taken assumes that HRM systems in general or HRM systems comprised of specific practices influence innovation capacity. Previous empirical studies lend support for the contention that HRM influences mechanisms such as development and exploitation of intellectual capital (Wright et al., 2001). Whereas Jiminez and Valle (2005) demonstrated a link between performance appraisal systems, incentive based compensation, and internal career opportunities with technological innovation, speculating that it is the impact of the HRM practices on employee participation that provides opportunities for technological innovation. In a similar vein, Shipton et al. (2005) provided evidence that combining training, appraisal and induction influences different stages of the organizational learning cycle (i.e. creation, sharing and implementation of knowledge). According to Collins and Smith (2006) HRM influences knowledge creation and new product development.

Shipton et al. (2006) showed that not only do training, appraisal, and induction impact technological innovation, but that the influence of these practices may differ according to the types of technological innovation activities (i.e. exploitative vs. explorative). Nonetheless, characteristics of the organization (e.g. size, external market, industry) are critical factors in determining the appropriate HRM practices for an innovation strategy. Smith et al. (2011) pointed that the ability of enterprises to innovate depends on the effective management of human resources and, in particular, the learning and development practices that enable enterprises to increase the skills of workers to innovate (human capital formation). 
This research will further explore the HR factors linked to organizations' technological innovation, in particular the study will adopt, HR factors related to technological innovation mentioned by Becker and Matthews, 2008.

The literature doesn't agree on an effective module of HR enhancing technological innovation. As far as studies show, it's obvious that the role of HR department isn't directly linked to technological innovation in Saudi industrial sector. HR technological abilities affect on innovation is unclear in the literature.

\section{Research Methodology}

\subsection{Research Tool}

Field surveys are used to collect the necessary data to come up with justifiable conclusions regarding the impact of HRM on organizations' innovation. Two questionnaires were developed. The first questionnaire contains questions seeking information about products and processes innovation as well as organizational and marketing innovation during the three-year period 2008 to 2010 inclusive. Most questions cover new or significantly improved goods or services or the implementation of new or significantly improved processes, logistics or distribution methods. The second questionnaire contained questions seeking data to measure HR practices in organizations.

\subsubsection{Innovation Survey Development}

After reviewing previous studies on the subject of the research and in order to serve the objective of this study, the Community Innovation Survey CIS4 was used to measure the organizations' innovation. CIS4 follows Oslo Manual (2005) guidelines in measuring innovation. Oslo Manual is a publication of the Organization for Economic Co-Operation and Development OECD and was published three times in the years 1992, 1997 and 2005 (Al-Kuaik, 2010).

The Community Innovation Survey CIS4 provides a good coverage of the items that could potentially be used to build innovation indicators (Herstad et al, 2008). The survey contains nine dimensions, (1) types of innovation, (2) information on the innovation activities and investments, (3) innovation objectives, (4) sources of information for innovation, (5) innovation collaboration, (6) results of the firm's innovation, (7) factors hampering innovation, (8) profiting from firm's innovation investment, (9) some context information about the firm.

\subsubsection{HRM Survey Development}

After reviewing previous studies on the subject of the research and in order to serve the objective of this study, HRM survey was designed based on overlapped questions on similar constructs in previous researches on HRM (Hester 2005; Doerflein 2006; Ferguson 2006; Palmer 2006). The $\mathrm{HRM}$ questionnaire consists of a list of HR potential practices that may affect the Technological Innovation in the organization. Based on the literature review and for the purpose of achieving the objectives of the research, Becker and Matthews (2008) study indicated the most influential HRM functions for effective organizations' technological innovation, was adopted in this research. Becker and Matthews (2008) found it clear that there is much overlap in the HR functions seen important to innovation through the literature review as mentioned in the previous chapter. These include the five following HR practices: (1) HR planning, (2) selection and attraction, (3) performance management, (4) recognition and reward systems, (5) training and development. 


\subsection{Primary Industry Sector in Jubail City}

The target population of this study is the Primary industries sector in Jubail City of Saudi Arabia. Primary industries are industries which dependent on natural resources such as oil, natural gas and minerals as raw materials to turn them into raw materials used in secondary or supporting industries. Jubail Produces $7 \%$ of the world's petrochemicals contributes $11.5 \%$ of the Kingdom's non-oil gross domestic product (GDP) and creates $85 \%$ of the Kingdom's non-oil exports. The Annual growth is sustained at $6 \%$. Therefore Jubail has attracted over $50 \%$ of the Kingdom's total foreign investment (2014 Annual report of the Royal Commission Jubail and Yanbu RCJY). 87\% of Saudi investment was in primary industries, which have reached to about 613 billion Saudi Riyals, $68 \%$ was invested in Jubail city.

\subsection{Study Sample}

Jubail primary industry companies consists of (25) companies. Given the nature of this study and since the population size was considered small the decision was to seek the necessary data from all the companies in the population. Therefore, (25) questionnaires distributed at the beginning of the month of February 2011, nineteen (19) companies completed and returned the questionnaires, which represents about (76\%) of the population. All (19) responses are analyzed which means $(100 \%)$ of the regained questionnaires. The questionnaires were distributed by the Public Relation (PR) department in Jubail primary industries companies through the (PR) Department of Royal Commission for Jubail (RCJ). Some collected via researcher's email, while most were hand redistributed and collected as a hard copy given the short response via email and after intensive follow-up via telephone, email, and personal visits.

\subsection{Data Analysis Procedures}

Statistical analysis was necessary to achieve the objectives of the study. Data analyzed using the Statistical Package for Social Sciences (SPSS) and using the following statistics:

- Cronbach's alpha.

- Pearson Correlation.

- Means.

- Standard deviation.

\subsection{Validity and Reliability of the Survey Instrument}

Since this study used the Community Innovation Survey CIS4 to measure the organizations' innovation. And CIS4 follows Oslo Manual (2005) guidelines in measuring innovation. Validity and reliability was tested for the HRM survey only. The HRM questionnaire was reviewed by a number of (3) university academics and (2) HR professionals to insure the face validity of the research tool and to guarantee the quality of translation into Arabic and the suitability to the environment of the research community. Their comments were taken and some paragraphs have been modified based on their recommendations. The names of these referees and their positions are seen in Appendix (1).

Also to verify the validity of the study tool, the Pearsons Coefficient of Correlation between the main scale about human resources and the subscales is calculated. Table (3-1) shows that the calculated Pearson's coefficient of correlation for the seven sub sections of the study tool were between (.673) and (.929). These results show that there is a statistically significant relation $(a=0.01)$ between the variables. This indicates that the study tool has the validity to meet the research objectives. 
Table (3-1): Pearsons Coefficient of Correlation for Validity of the Research Tool

\begin{tabular}{|c|c|c|c|}
\hline Number & Sub Scale & $\begin{array}{l}\text { Pearsons } \\
\text { Correlation }\end{array}$ & Significance \\
\hline 1 & Potential Qualities & $.673\left(^{* \star}\right)$ & 0.01 \\
\hline 2 & Technical possibilities & $.808\left({ }^{\star \star}\right)$ & 0.01 \\
\hline 3 & HR Planning & $.922\left(^{\star \star}\right)$ & 0.01 \\
\hline 4 & Selection and Attraction & $.929\left({ }^{\star \star}\right)$ & 0.01 \\
\hline 5 & Performance Management & $.825\left(^{* \star}\right)$ & 0.01 \\
\hline 6 & Recognition \& Reward system & $.920\left({ }^{\star \star}\right)$ & 0.01 \\
\hline 7 & Training\& Development & $.903\left({ }^{\star \star}\right)$ & 0.01 \\
\hline
\end{tabular}

A reliability analysis procedure was applied to make sure that the implemented tool was reliable in measuring the underlying elements. The reliability model of SPSS was used to assess the internal consistency of all factors through the determination of the Cronbach's alpha coefficient. The reliability criterion (Cronbach alpha) of each section was calculated and presented in table (3-2). According to George and Mallery (2003) Cronbach's alpha must be (0.7) or higher to be acceptable, the closer Cronbach's alpha coefficient is to (1.0) the greater the internal consistency of the items in the scale. The analysis indicated that all factors have coefficients alpha ranged from $(0.78)$ to $(0.96)$. Therefore, values of calculated alpha in this research work indicate high levels of reliability.

Table (3-2): Values of Cronbach's alpha in Questionnaire as an Indicator to Reliability

\begin{tabular}{|c|l|c|}
\hline Number & \multicolumn{1}{|c|}{ Sub Scale } & Cronbach's alpha \\
\hline 1 & Potential Qualities & 0.85 \\
\hline 2 & Technical possibilities & 0.82 \\
\hline 3 & HR Planning & 0.78 \\
\hline 4 & Selection and Attraction & 0.88 \\
\hline 5 & Performance Management & 0.79 \\
\hline 6 & Recognition \& Reward system & 0.87 \\
\hline 7 & Training\& Development & 0.92 \\
\hline & Total scale & 0.96 \\
\hline
\end{tabular}

\section{Results:}

The correlation between HRM and technological innovation in the Jubail primary industrial companies was analyzed and calculated using Pearson Correlation coefficient.

\subsection{Correlation between HRM and Innovation Type}

Pearson Correlations was calculated between human resources management and the type of innovation. Results of correlation are presented in table (4-1). 
Table (4-1): Correlation between HRM and Type of Innovation in Participants' Companies

\begin{tabular}{|c|c|c|c|c|}
\hline $\begin{array}{c}\text { Type of Innovation } \\
\text { Human Resources }\end{array}$ & $\begin{array}{c}\text { Product } \\
\text { Innovation }\end{array}$ & $\begin{array}{c}\text { Process } \\
\text { Innovation }\end{array}$ & $\begin{array}{c}\text { Marketing } \\
\text { Innovation }\end{array}$ & $\begin{array}{c}\text { Organizational } \\
\text { Innovation }\end{array}$ \\
\hline $\begin{array}{c}\text { The Role of HR } \\
\text { Department }\end{array}$ & .348 & $.492\left(^{*}\right)$ & .053 & -.326 \\
\hline $\begin{array}{c}\text { Technological } \\
\text { Potentials }\end{array}$ & $.495\left(^{*}\right)$ & .330 & .071 & -.281 \\
\hline HR Planning & $.486\left(^{*}\right)$ & $.605\left(^{* *}\right)$ & .123 & -.156 \\
\hline $\begin{array}{c}\text { Selection and } \\
\text { Attraction }\end{array}$ & .376 & $.576\left(^{* *}\right)$ & -.095 & -.049 \\
\hline $\begin{array}{c}\text { Performance } \\
\text { Management in }\end{array}$ & .192 & $.493\left(^{*}\right)$ & -.160 & .010 \\
\hline $\begin{array}{c}\text { Recognition \& Reward } \\
\text { System }\end{array}$ & .431 & $.647\left(^{* *}\right)$ & .057 & -.072 \\
\hline $\begin{array}{c}\text { Training \& } \\
\text { Development }\end{array}$ & $.472\left(^{*}\right)$ & $.531\left(^{*}\right)$ & .220 & -.090 \\
\hline
\end{tabular}

${ }^{\star *}$ Correlation is significant at the 0.01 level

* Correlation is significant at the 0.05 level

The results in table (4-1) show that:

- There is a significant relation ( $\alpha=0.05, r=.492)$ between the role of HR department and the process innovation in the companies of Jubail primary industries. This indicates that the increase in potential qualities of HR leads to increase in the process innovation.

- There is a significant relation $(\alpha=0.05, r=.495)$ between HR technological potentials and the product innovation in Jubail primary companies; the increase in technological potentials in HR leads to increase in the product innovation.

- There is a significant relation between the HR planning and the product innovation ( $\alpha$ $=0.05, r=.486)$, and between the HR Planning and the process innovation $(\alpha=0.01, r=.605)$ the companies of primary industries in Jubail Industrial City. This indicates that the increase in HR planning lead to increase in the product and process innovations.

- There is a significant relation $(\alpha=0.01, r=.576)$ between the selection and attraction in HR and the process innovation in the companies of primary industries in Jubail Industrial City. This indicates that the increase in selection and attraction activities in HR leads to increase in the process innovation.

- There is a significant relation $(\alpha=0.05, r=.493)$ between the performance management in $\mathrm{HR}$ and process innovation in the companies of primary industries in Jubail Industrial City. This indicates that the increase in performance management in HR leads to increase in the process innovation.

- There is a significant relation $(\alpha=0.01, r=.647)$ between the recognition and reward system and the process innovation in the companies of industries in Jubail Industrial City. This indicates that the increase in recognition and reward system lead to increase in the process innovation.

- There is a significant relation between the training and development in HR and the product innovation ( $\alpha=0.05, r=.472)$, and between the training and development in HR and the process innovation ( $\alpha=0.01, r=.531)$ in the companies of primary industries in Industrial City. This indicates that the increase in training and development in HR lead to increase in both the product innovation and the process innovation. 
Previous results support Shipton et al. (2006) note about the variation of HR influence according to the types of technological innovation activities.

\subsection{Correlation between HRM and Applying for Patents or Registering Trademarks}

To find the impact of HRM on applying for patents in the companies of primary industries in Jubail Industrial City, Pearson correlation is calculated, results are represented in table (4-2):

Table (4-2): Correlation between HRM \& Patents / Trademarks

\begin{tabular}{|l|c|c|}
\hline Human Resources & Patents & $\begin{array}{c}\text { Registered designs or } \\
\text { trademarks }\end{array}$ \\
\hline Potential Qualities of HR & .147 & .261 \\
\hline HR Technological Potentials & .218 & .324 \\
\hline HR Planning & .269 & .284 \\
\hline Selection and Attraction & .191 & .262 \\
\hline Performance Management & .013 & .186 \\
\hline Recognition \& Reward system & .264 & .272 \\
\hline Training \& Development & .172 & .350 \\
\hline${ }^{*}$ Correlation is significant at the 0.01 level \\
${ }^{*}$ Correlation is significant at the 0.05 level
\end{tabular}

Results show that there are no significant relations $(\alpha=0.05)$ between any of the subscales of HR and the patents in the companies of basic industries in Jubail Industrial City. Results also show that there are no significant relations $(\alpha=0.05)$ between any of the $(7)$ subscales of HR the registered designs or trademarks in the companies of basic industries in Jubail industrial City.

\subsection{Correlation between HRM and Innovation Activities}

To identify the impact of human resources management on the innovation activities, the Pearson correlations between the human resources indicators and the innovation activities is calculated. Table (4-3) shows the measured results.

Table (4-3): Correlation between HRM and Innovation Activities in Companies

\begin{tabular}{|c|c|c|c|c|c|c|}
\hline $\begin{array}{c}\text { Innovation activities } \\
\text { Human Resources }\end{array}$ & $\begin{array}{c}\text { Intramural } \\
\text { (in-house) } \\
\text { R\&D }\end{array}$ & $\begin{array}{c}\text { Extramural } \\
\text { R\&D }\end{array}$ & $\begin{array}{c}\text { Owning of } \\
\text { machinery, } \\
\text { equipment } \\
\text { and software }\end{array}$ & $\begin{array}{c}\text { Owning of } \\
\text { other } \\
\text { external } \\
\text { knowledge }\end{array}$ & Training & $\begin{array}{c}\text { Market } \\
\text { introduction of } \\
\text { innovations }\end{array}$ \\
\hline The Role of HR & .372 & .120 & -.053 & .120 & -.022 & -.229 \\
\hline HR Technological & $.608\left(^{* *}\right)$ & .111 & .067 & -.034 & .291 & .290 \\
\hline HR Planning & $.524\left(^{*}\right)$ & -.027 & .022 & -.155 & .197 & -.036 \\
\hline Selection and Attraction & $.581\left(^{* *}\right)$ & .000 & -.058 & -.143 & .267 & .016 \\
\hline Performance & $.587\left(^{* *}\right)$ & -.263 & -.066 & -.148 & .064 & -.063 \\
\hline Recognition \& Reward & $.521\left(^{*}\right)$ & .087 & -.078 & -.272 & .266 & .017 \\
\hline Training \& Development & $.657\left(^{* *}\right)$ & -.037 & .120 & -.168 & .285 & .285 \\
\hline
\end{tabular}

${ }^{* *}$ Correlation is significant at the 0.01 level

* Correlation is significant at the 0.05 level

Table (4-3) shows the following results:

- There is a significant relation $(\alpha=0.01, r=.608)$ between the HR technological potentials and the intramural $R \& D$ in the companies of primary industries in Jubail industrial City. This indicates that the increase in technological potentials in HR leads to increase in intramural R\&D. 
- There is a significant relation $(\alpha=0.05, r=.524)$ between the HR planning and the intramural R\&D in the companies of primary industries in Jubail industrial City which indicates that the increase in HR planning leads to increase in intramural R\&D.

- There is a significant relation $(\alpha=0.01, r=.581)$ between the selection and attraction in $H R$ and the intramural R\&D in the companies of primary industries in Jubail industrial City which indicates that the increase in selection and attraction in HR leads to increase in the intramural R\&D.

- There is a significant relation $(\alpha=0.01, r=.587)$ between the performance management in $H R$ and the intramural R\&D in the companies of industries in Jubail industrial City which indicates that the increase in performance management in HR leads to increase in the intramural R\&D.

- There is a significant relation $(\alpha=0.05, r=.521)$ between the recognition and reward system and the intramural R\&D in the companies of primary industries in Jubail industrial City which indicates that the increase in recognition and reward system leads to increase in the intramural R\&D.

- There is a significant relation $(\alpha=0.05, r=.657)$ between the training and development in $H R$ and the intramural R\&D in the Jubail companies of primary industries which indicates that the increase in training and development in HR leads to increase in the intramural R\&D.

- There is no significant relation $(\alpha=0.05)$ between the human resources management and the extramural R\&D in Jubail companies of primary industries.

- There is no significant relation $(\alpha=0.05)$ between the human resources management and the owning of machinery, equipment and software in the companies of primary industries in Jubail companies of primary industries .

- There is no significant relation $(\alpha=0.05)$ between the human resources management and the owning of other external knowledge in the companies of primary industries in Jubail companies of primary industries.

- There is no significant relation $(\alpha=0.05)$ between the human resources management and the training innovation activity in Jubail companies of primary industries.

- There is no significant relation $(\alpha=0.05)$ between the human resources management and the market introduction of innovations in Jubail companies of primary industries.

\subsection{Correlation between HRM and the Expenditure in Innovation Activities}

To identify the impact of human resources management on the expenditure in innovation activities, Pearson correlations between the human resources management practices and the expenditure in the innovation activities is calculated. 
Table (4-4): Correlation between HRM and Expenditure in Innovation Activities in Participants' Companies

\begin{tabular}{|l|c|}
\hline Human Resources & $\begin{array}{c}\text { Expenditure in } \\
\text { Innovation Activities }\end{array}$ \\
\hline The Role of HR Department & $.61\left(^{*}\right)$ \\
\hline Technological potentials & $.627\left(^{\star}\right)$ \\
\hline HR Planning & -.063 \\
\hline Selection and Attraction & $.717\left(^{*}\right)$ \\
\hline Performance Management & .308 \\
\hline Recognition \& Reward system & $.699\left(^{*}\right)$ \\
\hline Training \& Development & $.598\left(^{*}\right)$ \\
\hline
\end{tabular}

${ }^{* *}$ Correlation is significant at the 0.01 level

* Correlation is significant at the 0.05 level

The results in table (4-4) show that:

- There is a significant relation ( $\alpha=0.05, r=.615)$ between the role of HR department and the expenditure in innovation activity in the companies of primary industries in Jubail Industrial City which indicates that the increase in potential qualities of HR leads to increase in the expenditure in innovation activity and the expenditure in innovation activities increases the potential qualities of HR.

- There is a significant relation ( $\alpha=0.05, r=.627)$ between HR technological potentials and the expenditure in innovation activity in Jubail companies of primary industries, which indicates that the increase in technological potentials in HR leads to increase in expenditure in innovation activities.

- There is a significant relation $(\alpha=0.05, r=.717)$ between the selection and attraction in $\mathrm{HR}$ and the expenditure in innovation activities in Jubail companies of primary industries in which indicates that the increase in selection and attraction in HR leads to increase in expenditure in innovation activities .

- There is a significant relation ( $\alpha=0.05, r=.699)$ between the recognition and reward system and the expenditure in innovation activities in Jubail companies of primary industries which indicates that the increase in recognition and reward system increases the expenditure in innovation activities.

- There is a significant relation ( $\alpha=0.05, r=.598$ ) between the training and development in $\mathrm{HR}$ and the expenditure in innovation activities in Jubail companies of primary industries which indicates that the increase in training and development in HR increases the expenditure in innovation.

- There is no significant relation $(\alpha=0.05)$ between HR planning and the expenditure in innovation activities in the companies of primary industries in Jubail industrial City.

- There is no significant relation $(\alpha=0.05)$ between the performance management in $\mathrm{HR}$ and the expenditure in innovation activities in the companies of primary industries in Jubail industrial City.

\subsection{Correlation between HRM and Factors Hampering Innovation}

To determine the impact of HRM on the factors that hamper the innovation in Jubail primary industrial companies Pearson correlations between HRM practices and the factors is calculated. Results are shown in table (4-5). 
Table (4-5): Correlation between HRM and Factors Hampering Innovation in Participants' Companies

\begin{tabular}{|l|c|c|c|}
\hline Human Resources & Cost Factors & $\begin{array}{c}\text { Knowledge } \\
\text { Factors }\end{array}$ & Market Factors \\
\hline The Role of HR Department & -.245 & -.383 & -.420 \\
\hline HR Technological Potentials & $-.547\left(^{*}\right)$ & $-.551\left(^{*}\right)$ & $-.555\left(^{*}\right)$ \\
\hline HR Planning & $-.467\left(^{*}\right)$ & $-.517\left(^{*}\right)$ & -.302 \\
\hline Selection and Attraction & $-.508\left(^{*}\right)$ & -.438 & $-.462\left(^{*}\right)$ \\
\hline Performance Management & -.426 & $-.522\left(^{*}\right)$ & $-.545\left(^{*}\right)$ \\
\hline Recognition \& Reward system & -.300 & -.452 & -.278 \\
\hline Training \& Development & -.411 & $-.539\left(^{*}\right)$ & -.343 \\
\hline
\end{tabular}

** Correlation is significant at the 0.01 level

* Correlation is significant at the 0.05 level (2-tailed).

The results in table (4-5) show that:

- There is a significant negative relation $(\alpha=0.05)$ between the technological potentials in HR and the three factors hampering innovation activities; (Cost Factors $r=-.547$ ), (Knowledge Factors $r=-.551$ ) and (Market Factors $r=-.555$ ). This indicates that the increase in technological potentials in HR decreases the effect of these factors.

- There is a significant negative relation $(\alpha=0.05)$ between the HR planning in HR and the two factors of (Cost Factors $r=-.467$ ) and (Knowledge Factors $r=-.517$ ). This indicates that the increase in planning in HR decreases the effects of these factors in Jubail primary industrial companies.

- There is a significant negative relation $(\alpha=0.05)$ between the selection and attraction in $\mathrm{HR}$ and two of the factors hampering innovation activities which are the cost factors $(\mathrm{r}=-.508)$ and the market factors $(\mathrm{r}=-.462)$.

- There is a significant negative relation $(\alpha=0.05)$ between the performance management in HR and the factors of Knowledge $(r=-.522)$ and Market $(r=-.545)$.

- There is a significant negative relation $(\alpha=0.05)$ between the training and development in $\mathrm{HR}$ and the factor of Knowledge $(r=-.539)$ indicating that the increase in the training and development in HR leads to decrease in this factor in Jubail primary industrial companies.

- There is no significant positive relation $(\alpha=0.05)$ between the potential qualities of HR and the factors of cost, knowledge and market in Jubail primary industrial companies.

- There is no significant positive relation $(\alpha=0.05)$ between the recognition and reward system and the factors hampering innovation activities in the companies of primary industries in Jubail industrial City .

\subsection{Correlation between HRM and Profiting from Innovation Investments}

To identify the impact of human resources management on the profiting from innovation investment, the researcher calculated Pearson correlations for the responses of the sample. Results are shown in table (4-6). 
Table (4-6): Correlation between HRM and Profiting From Innovation Investments In Participants' Companies

\begin{tabular}{|l|c|}
\hline Human Resources & $\begin{array}{c}\text { Profiting from } \\
\text { Innovation } \\
\text { Investment }\end{array}$ \\
\hline Potential qualities of HR & .187 \\
\hline Technical possibilities in HR & .283 \\
\hline HR Planning & .251 \\
\hline Selection and Attraction in HR & .245 \\
\hline $\begin{array}{l}\text { Performance Management in } \\
\text { HR }\end{array}$ & .126 \\
\hline Recognition \& Reward system & .336 \\
\hline $\begin{array}{l}\text { Training \& Development in } \\
\text { HR }\end{array}$ & $.514\left(^{*}\right)$ \\
\hline
\end{tabular}

** Correlation is significant at the 0.01 level

* Correlation is significant at the 0.05 level

The results show that:

- There is a significant relation ( $\alpha=0.05, r=.514)$ between the training and development in HR and the profiting from innovation investment in Jubail companies of primary industries. This indicates that the increase in training and development in HR leads to increase in the profiting from innovation investment.

- There is no significant relation $(\alpha=0.05)$ between other HR indicators and profiting from innovation investment in the companies of primary industries in Jubail

Table (4-7) Demonstrates of Correlation Between HRM \& Innovation in Participants' Companies. 
Table (4-7): Correlation between HRM \& Innovation in Participants' Companies

\begin{tabular}{|c|c|c|c|c|c|c|c|c|}
\hline \multirow{2}{*}{ Innovation } & \multicolumn{2}{|c|}{ Innovation Type } & \multirow{2}{*}{$\begin{array}{c}\begin{array}{c}\text { Innovation } \\
\text { Activity }\end{array} \\
\text { Intramural } \\
\text { (in-house) } \\
\text { R\&D }\end{array}$} & \multirow{2}{*}{$\begin{array}{c}\text { Expenditure } \\
\text { in Innovation } \\
\text { Activities }\end{array}$} & \multirow{2}{*}{$\begin{array}{c}\text { Innovation } \\
\text { Objectives } \\
\text { Process } \\
\text { Innovation }\end{array}$} & \multicolumn{3}{|c|}{$\begin{array}{l}\text { Factors Hampering } \\
\text { Innovation }\end{array}$} \\
\hline & Product & Process & & & & $\begin{array}{c}\text { Cost } \\
\text { Factors }\end{array}$ & $\begin{array}{l}\text { Knowledge } \\
\text { Factors }\end{array}$ & $\begin{array}{l}\text { Market } \\
\text { Factors }\end{array}$ \\
\hline $\begin{array}{c}\text { Qualities of } \\
\text { HR }\end{array}$ & - & $\begin{array}{l}.492 \\
\left({ }^{*}\right)\end{array}$ & - & $.615\left(^{\star}\right)$ & $.542\left(^{*}\right)$ & - & - & - \\
\hline $\begin{array}{c}\text { HR } \\
\text { Technological } \\
\text { Abilities }\end{array}$ & $\begin{array}{c}.495 \\
\left({ }^{*}\right)\end{array}$ & & $.608\left(^{* \star}\right)$ & $.627\left(^{\star}\right)$ & & $\begin{array}{c}-.547 \\
\left(^{*}\right)\end{array}$ & $-.551\left(^{*}\right)$ & $\begin{array}{c}-.555 \\
\left(^{*}\right)\end{array}$ \\
\hline HR Planning & $\begin{array}{c}.486 \\
\left({ }^{*}\right)\end{array}$ & $\begin{array}{l}.605 \\
\left({ }^{* \star}\right)\end{array}$ & $.524\left(^{*}\right)$ & - & - & $\begin{array}{c}-.467 \\
\left({ }^{*}\right)\end{array}$ & $-.517\left(^{*}\right)$ & - \\
\hline $\begin{array}{l}\text { Selection and } \\
\text { Attraction in }\end{array}$ & - & $\begin{array}{l}.576 \\
\left({ }^{* \star}\right)\end{array}$ & $.581\left(^{\star \star}\right)$ & $.717\left(^{*}\right)$ & & $\begin{array}{c}-.508 \\
\left({ }^{*}\right)\end{array}$ & -.438 & $\begin{array}{c}-.462 \\
\left(^{*}\right)\end{array}$ \\
\hline $\begin{array}{l}\text { Performance } \\
\text { Management }\end{array}$ & - & $\begin{array}{c}.493 \\
\left({ }^{*}\right)\end{array}$ & $.587\left({ }^{\star \star}\right)$ & - & - & - & $-.522\left(^{*}\right)$ & $\begin{array}{c}-.545 \\
\left(^{*}\right)\end{array}$ \\
\hline $\begin{array}{l}\text { Recognition \& } \\
\text { Reward system }\end{array}$ & - & $\begin{array}{l}.647 \\
\left({ }^{* \star}\right)\end{array}$ & $.521\left(^{*}\right)$ & $.699\left(^{*}\right)$ & - & - & - & - \\
\hline $\begin{array}{c}\text { Training \& } \\
\text { Development }\end{array}$ & $\begin{array}{c}.472 \\
\left({ }^{*}\right)\end{array}$ & $\begin{array}{c}.531 \\
\left({ }^{*}\right)\end{array}$ & $.657\left(^{\star \star}\right)$ & $.598\left(^{\star}\right)$ & - & - & $-.539\left(^{*}\right)$ & - \\
\hline
\end{tabular}

${ }^{* *}$ Correlation is significant at the 0.01 level

* Correlation is significant at the 0.05 level

\subsection{Main Results for HRM Impact on Technological Innovation}

The correlation between HRM and technological innovation was carried out. Results show that there is a significant positive relation between HR indicators believed to affect innovation and some technological innovation indicators in Jubail primary industrial companies.

1. The high involvement of HR in the company's strategy has positive effect on process innovation and process innovation objectives.

2. HR Technological potentials is positively relative to product innovation and R\&D innovating activity, HR technologies may also effect the innovation activities expenditure. Whereas there is no significant relation between HR technologies and factors hampering innovation.

3. HR planning has a positive influence on product and process innovation.

4. The increase in HR planning decreases the effects of cost and knowledge factors hampering technological innovation in Jubail primary industrial companies.

5. A good system for employees' selection and attraction can positively affect product innovation; it is also positively relevant to the innovation expenditures. The improvement in the HR selection and attraction system can also decrease cost and market factors hampering innovation in Jubail primary industrial companies.

6. Performance management has a significant positive effect on Jubail primary industrial companies' process innovation, it is also proven that the more developed performance management is the less effect knowledge and market factors has on the innovation activities. 
7. Recognition and Reward system has a positive effect on process innovation; it is also positively relevant to the innovation expenditures.

8. Training and Development positively influences both product and process innovation and increases innovation expenditures, training may also increase profiting from innovation investment. Enhancing training and development in Jubail primary industrial companies leads to decrease knowledge factors causing to hamper innovation projects.

9. All HR indicators positively influence the in-house R\&D innovation activity.

10. Results show that HR indicators adopted in this study have no significant effect on changes in how companies markets goods and services, "marketing innovation". It is important to note that SABIC which comprise 11 companies out of the 25 of the research population, relies on marketing centers in Europe and the United States among other distribution points in order to enhance competitiveness by being closer to their customer for better understanding of clients needs and to meet their demands.

\section{Conclusions}

Even though the results of this study cannot be generalized, results from this research are promising and concluded bellow.

1. It is concluded that HRM has a direct impact on technological innovation in Jubail primary industrial companies.

2. Enhancing technological innovation in industrial organization is possible through integrating HRM practices, developing HR activities and emphasizing on HR role in the industrial organizations' strategic planning. 3. HR technological abilities can enhance "product innovation, reduce the influence of factors hampering innovation and increase the R\&D innovation activities in the primary industrial companies in Jubail city.

4. Results also show the high correlation between the recognition and reward system in industrial companies and "process innovation" activities which indicates the importance of the workforce spirits.

5. The methodology used to measure the relation between HRM and technological innovation is suitable and could be used to enhance technological innovation in industrial organizations.

\section{REFERENCES}

Al-Kuaik, K. (2010). Study of Factors Effecting Innovation Process and its Role in Enhancing Firms Performance, Unpublished Master thesis, Arabian Gulf University, Manamah, Bahrain.

Abdullah, Z. Ahsan, N., \& Alam, S. (2009). The Effect of Human Resource Management Practices on Business Performance among Private Companies in Malaysia. International Journal of Business and Management, 4 (6), 65-72.

Bessant, J., \& Tidd, J.(2007). Innovation and Entrepreneurship. Chichester: JohnWiley \& Sons.

Becker, K., \& Matthews, J. (2008). Linking HRM and innovation. Paper presented at 2nd ANZAM Conference "Managing in the Pacific Century". Auckland, New Zealand.

Bloch, C. (2008). Innovation indicators and performance : An analysis for Danish firms. Danish Centre for Studies in Research and Research Policy. University of Aarhus, Denmark

Bessant, J. (2003). High-Involvement Innovation: Building and Sustaining Competitive Advantage through Continuous Change. Chichester: John Wiley \& Sons.

Collins, C. J., \& Smith, K. G. (2006). Knowledge exchange and combination: The role of human resource practices in the performance of high technology firms. Academy of Management Journal, 49(3), 544560.

Doerflein, K. (2006). The impact of human resource management on supply chain management, unpublished DBA, Purdue University, USA. 
Delany, J., \& Huselid, M. (1996). The Impact of Human Resource Management Practices on Perceptions of Performance in For-Profit and Nonprofit Organizations. Academy of Management Journal, 39(4), 949969.

Ferguson, K. (2005). Human resources management system and firm performance. Unpublished DBA, University of Louisville, USA.

Hester, L. (2005). Impact of Strategic Human Resources Management on Organizational Performance, unpublished DBA, Nova Southeastern University, USA

Hull, F. \& Azumi, K. (1984). Organizing resources for innovation and productivity: A preliminary abstract draft. Technovation, 2(4), 293-297.

Jiminez- Jiminez, D. \& Sanz-Valle, R. (2005). Innovation and human resource fit: An empirical study. International Journal of Manpower, 36(4), 364-398.

Jorgensen, F., Becker, K., \& Matthews, K. (2009). Human Resource Management and Innovation: What are Knowledge-Intensive Firms Doing?. Paper presented at the 10PthP international CINet conference "Enhancing the Innovation Environment". Brisbane, Australia.

Laursen, K., \& Foss, N. I. (2003). New human resource management practices, complementarities and impact on innovation performance. Cambridge Journal of Economics, 27(2), 243-283.

Mathauer I., \& Imhoff, I. (2006). Health worker motivation in Africa: the role of nonfinancial incentives and human resource management tools. Human Resources for Health, 4(24), Published online.

Organization For Economic Co-Operation and Development - OCED (2005). Oslo Manual, Guidelines For Collecting And Interpreting Innovation Data. A joint publication of OECD and Eurostat. 3rd addition.

Palmer ,L. (2006). The impact of human recourses management practices on Employees' commitment, unpublished DBA, Nova Southeastern University, USA.

Porter, M. (1990). The Competitive Advantage of Nations. Harvard Business Review, March-April (2), 73-93.

Scarbrough, H. (2003). Knowledge management, HRM and the innovation process. International Journal of Manpower, 24(5), 501-516.

Shipton, H., West, M. A., Dawson, J., Birdi, K., \& Malcolm, P. (2006). HRM as a predictor of innovation. Human Resource Management Journal, 16(1), 3-27.

Smith, A., Courvisanos, J., Tuck, J., \& McEachern, S. (2011). Building Innovation Capacity: The role of Human Capital Formation in Enterprises. Review of the literature. NCVER Occasional Paper Series, National Centre for Vocational Education Research. http://www.ncver.edu.au/publications/2341.html.

Ulrich , D. (1997). H3Tuman Resource Champions3T: 3TThe Next Agenda for Adding Value and Delivering.3T 3TBoston: Harvard Business School Press.

Wright, P. M., Dunford, B. B., \& Snell, S. A. (2001). Human resources and the resource-based view of the firm. Journal of Management, 27(6), 701-721.

Yoon, S. Cho 2004, 'Examining the Impact of Human Resource Management: A Performance-based Analytic Model', Dissertation, University of Nevada, Las Vegas. 